\title{
Sanat ve Tasarım Alanlarında Maket Yapımının Tasarım, Üretim ve Sunum Așamalarına Etkileri
}

Atay GERGIN *

Özet

Günümüzde sanat ve tasarım alanlarında, tasarım ve sunum aşamalarında kullanılan modelleme metotlarından biri olan fiziksel maket yapımının; tasarım, sunum ve üretim teknikleri üzerindeki etkisini anlayabilmek için, maket olgusunun hem tarihsel hem de güncel anlam ve yöntemlerini bilmekte yarar vardır. İnsan fizyolojisinin üç boyutlu görsel algılama yapısının, bu yapıya hitap eden ve bu çalışmada odak alınan her türlü sanatsal veya tasarım içerikli uyarıcı ile ilişkisinin irdelenmesi de maket olgusunun etkilerinin anlaşılması anlamında faydalı olacaktır. Günümüzün teknolojik yapısına bağlı olarak gelişen dijital modelleme yöntemlerinin bu iletişim platformundaki yeri ve fiziksel modellerle kıyaslanması da bir tartışma konusudur. Maket yapımı ve kullanımının pozitif etkilerine vurgu yapılan bu çalışmada; sanat tasarım alanları dışında kalan ve maket kullanımından fayda sağlaması muhtemel alanlara da gönderme yapılmış ve fiziksel maketin sanat ve tasarım alanlarındaki güncel gereklilik durumu değerlendirilmiştir.

Anahtar So̊zcükler: Maket, Model, Fiziksel Model, Sanat, Tasarım, Sahne Tasarımı, Mimarlık.

\section{The Effects of Model Making in the Process of Design, Production and Presentation of Art and Design}

\section{Abstract}

Today, to understand the effect of material model making which is one of the modelling methods used in the process of design and production of art and design, presentation and production techniques, it's necessary to know not only the current meaning and methods but also the historical meaning of modelling. The three dimensional perception of human and the relation between him/her and the designs discussed in this study are examined to understand the effect of model making. The place of the digital modelling methods and to compare it with physical modelling is another discussion topic. In this paper, which puts emphasis on the positive effects of producing and using models, certain attribution is made to fields that may probably be useful other than art and design; and, the contemporary necessity of physical modelling in the fields of art and design is evaluated. 


\section{Giriş}

Tasarım ve üretim sürecinde neden maket yapıyoruz? Sanat eseri veya tasarım ürününün niteliklerini tanımlamak ve keşfetmek veya onu sunup anlatabilmek için neden makete ihtiyaç duyuyoruz? Bu soruların en belirgin yanıtı üç boyutlu maketin gerçekliği ve somutluğunda yatıyor diyebiliriz. Maket, tasarımın diğer iki boyutlu medya tekniklerine göre daha net, daha titiz bir deneyim ve tavırla şekillendirilmesine ve de hedef izleyicisine aktarılabilmesine olanak sağlamaktadır. Final yapısı üç boyutlu olacak şekilde ön görülen bir sanat veya tasarım projesinin tasarım çalışmaları iki boyutlu dijital ve fiziksel düzlemlerde tamamlanmış olsa da, eser fiziksel olarak üç boyutlu düzlemde üretilene kadar tam olarak anlamlı görünmeyebilmektedir (Dunn, 2010: 20).

Bunu şu şekilde açıklayabiliriz: Kavram oluşturmanın başlangıcı, şeklin algılanma süreciyle belirlenmektedir. Şekillerin ve nesnelerin algılanma biçimi, uyarıcı malzemede bulunan ya da bu malzemeye yüklenen yapısal özelliklerin kavranması şeklinde oluşur. Yani bir algısal örüntü, ne denli örgütlü ise kolaylıkla tanınma şansı da 0 denli artmaktadır (Arnheim, 2009: 43,45). İnsan, çevresi ile olan ilişkilerinin önemli bir boyutunu görsel yolla sağlamaktadır. İngiliz filozof ve araştırmacı John Locke'a göre Insan; \%1 deneyerek, \%2 dokunarak, \%4 koklayarak, \%10 duyarak, \%83 oranda da çevresini gözlemleyerek öğrenmektedir (Uçar, 2004: 61'den). Özellikle de üç boyutlu algıya hitap edecek olan sanat veya tasarım nesneleri için, estetik görünümlerin ve görüntülerin etkileri ancak üç boyutlu düzlemde algılanabildikleri zaman anlama çevrilebilmektedir (Uçar, 2004: 61). Bu nedenle, öğrenme içerisinde \% 83'lük bir alanı kapsayan görsel bölümde iletişimin doğru ve yeterli sağlanamadığı durumlarda, sanat ve tasarım nesnelerinin hem tasarım hem uygulama hem de algılanma süreçlerinde bozukluklar ve eksiklikler meydana gelmektedir. Örneğin dijital modelleme teknikleri ile üç boyut yanılsaması merkezli yapılan ve iki boyutlu düzlemlerde sunulan tasarım çalışmaları, önemli ölçüde görsel veri içermelerine rağmen üçboyutlu gerçeklik algımızın beklentisi karşısında eksik kalabilmektedirler.

Bu doğrultudan baktığımızda maket; temsil ile gerçekliğin arasında köprü görevi gören bir tasarlama aracı ve bir fikrin fiziksel sunumu olmasının yanı sıra, elle tutulur gerçek bir nesne olarak da öne çıkmaktadır. Maket aracılığıyla, çizimle ifade edilmesi zor olan ışık, gölge ve malzemelerin birbirleri ile ilişkisi gibi şeyler, doğrudan doğruya gösterilebilmektedir. Tek bakış açısı sunan doğrusal pers pektif çizimlerinin aksine, maketin etrafında hareket edilebilir veya maket hareket ettirilerek proje pek çok farklı açıdan değerlendirilebilir. (Spankle, 2012: 100).

Günümüz tasarımcısı için tasarımın her alanında, her düzeyinde ve her noktasında yaratıcı olmak kaçınılmaz bir zorunluluktur. Bu zorunluluk, yaratıcılığın yöntem ve tekniklerinin sistematik bir hale getirilerek geliştirilmesi gerekliliğini de beraberinde getirmektedir. Geliştirilecek olan bu sistemlerin kolay ve güvenli bir biçimde kullanılabilmesi de tasarım süreçlerinin aşamalarının süratle aşılabilmesine olanak sağlayacaktır. Bu noktada en uygun araç ve yöntemlerin seçilmesi ve geliştirilmesi, uygulama veya üretim aşamalarında ortaya çıkabilecek olan her türlü olumsuz sonucu ayrıntılı bir şekilde önceden belirleyerek, geliştirme ve düzeltmeler anlamındaki çözümleri proje daha tasarım aşamasındayken bulabilmek anlamında büyük önem taşımaktadır (Küçükerman, 1996: 39). Maket olgusunu bu bağlamda düşünerek değerlendirmek ve tasarım, uygulama ve sunum araçları listesinin ilk sıralarına yerleştirmek önemli bir avantaj sağlayacaktır.

Sanatçılar ve tasarımcıların hayli gelişmiş fikir üretme, geliştirme ve uygulama yöntemi bilgisine sahip olmaları beklenmektedir. Fikirlerini aktarmak için kullandıkları medya çeşitliliği ve zenginliği de sanatçı ve de tasarımcı kimliklerinin çekirdeğini oluşturmaktadır (Dunn, 2010: 7). Bu bağlamda, bir medya çeşitliliği olarak düşünülerek, üç boyutlu bir sanat veya tasarım nesnesinin tasarlanma aşamasında maketinin yapılması; oluşan ilk fikirlerin gelişmesine yardımcı olarak bu fikirlerin görsel izdüşümünü zihnimizde canlandırmak yerine, onları üç boyut algımıza hitap eden bir nesnellik duygusu ile deneylememize yardımcı olacaktır.

Tasarımcılar keşfetmek, şekillendirmek ve geliştirmek amaçlı oluşturdukları fikirlerini üç boyutlu olarak aktarabilmek için maket yapar. Ancak maket özel bir amaca ve hedefe sahiptir. Tüm fikirleri, sanat veya tasarım nesnesinin her bileşenini tek bir maket üzerinde sunabilmek pek mümkün değildir. Başka bir deyişle her maketin işlevi bir diğerinden farklı olabilir. Örneğin bazı maketler henüz olgunlaşmamış fikirleri tartışarak bir tasarlama ve konsept geliştirme aracı ya da bir deney ekipmanı olarak iş görebilir. Kimi maketler de daha gelişmiş bir bakış ve uygulama yöntemiyle, tasarım süreci sonlanmış bir eser veya nesneyi hedef izleyiciye sunmak, tanıtmak ve tasarımcı veya sanatçının bakış açısının nesnel bir açıdan pay- 


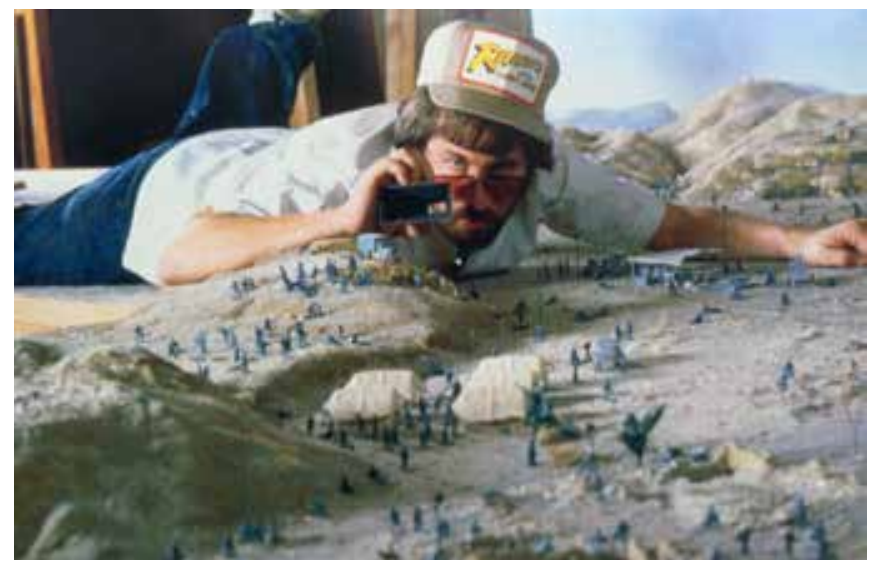

Resim 1. Steven Spilberg 'Indiana Jones-Riders Of The Lost Ark' filminin setinde kullanacağı kamera açılarını bir taslak maketi üzerinde inceliyor.

laşılmasını sağlamak için kullanılabilirler. Yani maketlerin fonksiyonları onları kimin neden kullandığına göre de değişiklik gösterebilmektedir (Dunn, 2010: 8-9).

Tasarım aşamalarının zaman kısıtlamaları açısından düşünüldüğünde de fiziksel maketin en çarpıcı avantajlarından birisi hızlı üretilebilirliğidir. Ekip halinde çalışan tasarımcılar malzeme, form, boyut ve renk hakkındaki fikirlerini de kendi aralarında maketler yardımıyla son derece etkili bir erişilebilirlikle paylaşabilirler. Maket kullanımı, dijital modelleme teknikleri veya çizim, boyama, kolaj gibi iki boyutlu fiziksel düzlemdeki tasarlama araçlarıyla kıyaslandığında da; gerçek dünyadaki boyut, biçim, renk ve doku gibi görsel anlamda zengin bilgi kaynaklarını farklı ölçeklerde ödünç alarak, üç boyutlu bir görsel dil oluşturabilme özelliği ile de öne çıkmaktadır. Maketin boyutu tasarım sürecinin farklı safhalarının gerekliliklerine göre değişken ölçeklerde olabilmektedir. Dolayısı ile maket, karşımıza kolay algılamayı sağlayıcı bir platform olarak çıkmakta ve tasarım fikirlerinin tüm özelliklerinin daha net ve etkili biçimde aktarılabilmesine olanak sağlamaktadır (Dunn, 2010: 5).

Maketlerin birer iletişim platformu olarak da algılanabileceğini savunan Akiko Busch'a göre, ölçekli maketin minyatür dünyası ile tasarımcının kurduğu ilişkinin bir otorite hissi yaşatması nedeniyle (Resim 1), pratik çözümlere ve uygulama yöntemlerine dair alınan kararların özgüven içeren bir yapıyla bağlantılı olarak, yerinde ve doğru olmasında da büyük etkisi vardır. Bir maket üzerindeki tasarım bileşenleri gerçek dünyaya göre çok daha kolayca değiştirilebilir, manipüle edilebilir, gözlemlenebilir ve anlaşılabilir bir fiziksel yapıya sahiptir. Bu da üretilecek olan eserin kendisinden önce maketiyle bir etkileşim oluşturarak tasarım problemleriyle daha rahat ve samimi bir iletişim kurulmasına neden olmaktadır (Dunn, 2010: 20).

\section{Maketin Tarihi}

Tasarım fikirlerinin aktarım aşamasında oluşan boşlukları doldurmak için Antik dönemlerden başlayarak, tarih boyunca farklı tiplerde maketler kullanılmıştır. Heredot'un beşinci kitabı olan Terpsichore'de bir tapınak inşası için kullanılan küçük ölçekli bir modelden bahsedilmektedir. İsa'dan önce beşinci yüzyıla işaret eden bu bilgi, bir tasarım aracı olarak maket kullanımına dair kaydedilen ilk referans olarak kabul edilmektedir (Dunn, 2010: 14). Ayrıca Antik Dönem mimarisinde sıklıkla kullanılan çeşitli sütunların tasarımları için bire bir ölçekli prototip modellerinin yapıldığı da bilinmektedir. Ortaçağ’da da dönemin estetik işleme ve boyutlandırma konusundaki az gelişsmişliği nedeniyle kaba, ayrıntısız ve teknik kullanım açısından yetersiz olmalarına rağmen az sayıda da olsa kilise mimarisi için kullanılmış maketlerin kayıtlarına rastlanmıştır (Dunn, 2010: 14). Bu köklü geçmişe rağmen maketlerin bugün bildiğimiz anlamda bir tasarım aracı olarak etkili bir biçimde kullanılmasına dair ilk önemli kayıtlar on dördüncü yüzyılı işaret etmektedir. Bu yüzyılın sonlarına doğru Filippo Brunelleschi'nin yaptığı Floransa Katedrali'nin ayrıntılı ve işlevsel bir tasarım maketinin yapıldığı bilinmek-

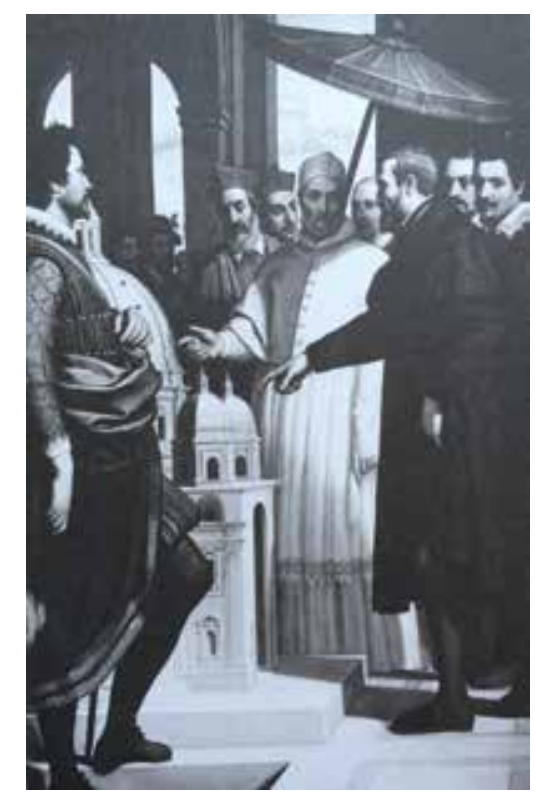

Resim 2. Michalengelo'nun Papa IV. Paul'e Roma St. Peter Katedrali'nin maketini sunuşunu gösteren Domenico Cresti tablosu. 
tedir. Takip eden dönemlerde, Erken Rönesans mimarları için popülerlik kazanmaya başlayan ölçekli maket kullanımının giderek gelişen örneklerini, on altıncı yüzyılda kilise mimarisi için yapılan ve ayrıntılı bir şekilde kayıt altına alınan tasarım maketlerinde izleyebilmekteyiz. On yedinci yüzyılın başlarında, Michalengelo'nun Roma'da yaptığı St. Peter Katedrali'nin maketinin sunumunu gösteren 1620 tarihli Domenico Cresti tablosu (Resim 2), bu dönemde maket yapımı ve kullanımının önemine işaret etmekle birlikte maketin bir tasarım ve keşif aracı olmanın yanı sıra bir sunum aracı olarak da kullanılmaya başlandığının göstergesidir (Dunn, 2010: 15).

Fiziksel modeller Rönesans döneminde özellikle Avrupa'da çok popüler bir araç haline gelmiş ve genellikle bir mimari düşünceyi tarif etmenin tek yolu olarak değerlendirilmiştir. İki boyutlu mimari çizimler, ancak on dokuzuncu ve erken yirminci yüzyılda gelişen Beaux Arts akımı döneminde mimari ifadenin ana yöntemi olmaya başlamıştır. Ancak 1900 'lerin ortalarından itibaren mimarlar, yeniden fiziksel modellerin düşüncelerini iletmek ve biçimlendirmek açısından daha pratik ve faydalı olduğuna inanmaya başlamışlardır (Farrelly, 2012: 118).

On sekizinci yüzyılda geliştirilen malzeme işleme tekniklerinin de etkisiyle maket, mimarinin yanı sıra sanat eğitiminde de kâğıt üzerindeki iki boyutlu tasarımlara destek olarak, bazen de öncelikli tasarım aracı olarak kullanılmaya başlamıştır. Takip eden süreçte birçok deneysel

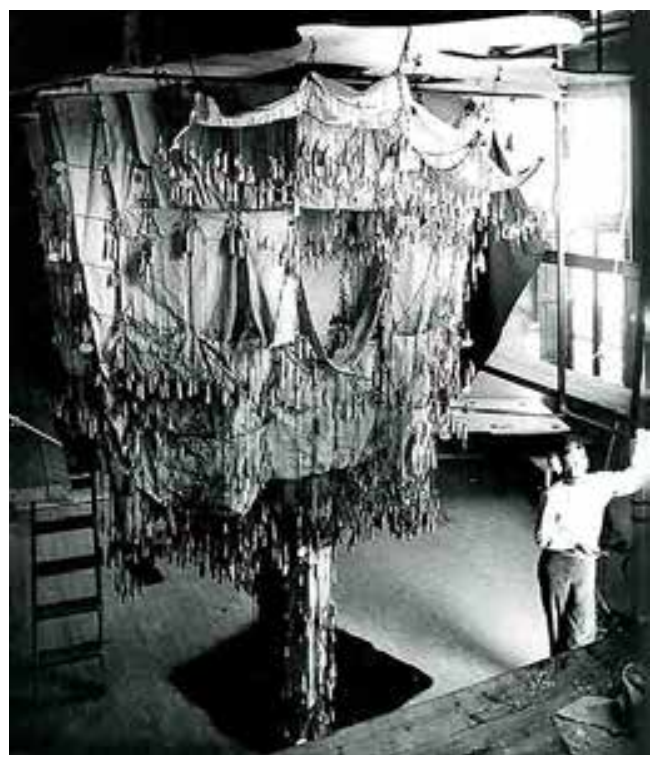

Resim 3. Antonio Gaudi La Sagrada Fanilia Kilisesinin taşıyıcı sistemlerini çözmek için kullandığı bir statik maketi ile birlikte. yöntemle yeni maket yapım teknikleri geliştirilmiş ve maketlerin kullanım alanları mimari ve sanatsal alanlarla birlikte endüstriyel alanlara da kayarak genişlemiştir. Örneğin Katalan mimar Antonio Gaudi, Barselona'daki La Sagrada Familia Katedrali'nin karmaşık yapısal biçimlerini geliş̧irebilmek için ağırlıklı olarak çeşitli ölçeklerdeki çok sayıda maketten faydalanmıştır (Resim 3) (Farrelly, 2012: 118).

1920 yılında 3. Enternasyonal için Vladimir Tatlin tarafından tasarlanan anıt için bire bir ölçekte yapılan ve sonraki tarihlerde birçok reprodüksiyonu yapılan maket, iddialı ve devrimsel tasarımı nedeniyle maket tarihinin en önemli eserlerinden biri olarak kabul edilmektedir (Arredmento Mimarlık, 2013: 72). Yirminci yüzyıla geldiğimizde ise maket yapımı ve kullanımı sanatçılar için en önemli tasarım ve üretim araçlarından biri haline gelmiştir. Örneğin Bauhaus akımının öncülerinden olan Walter Gropius eserlerinin tasarım aşamasında kâğıt üzerinde iki boyutlu çizimler yapmak yerine, üç boyutlu maketler yaparak yeni fikirler keşfetmeyi denemiştir (Dunn, 2010: 16).

Bu noktadan sonra maket; sanat ve tasarımın tanımlama, keşfetme ve değerlendirme aşamaları için güçlü bir iletişim aracı olarak gelişmeye devam etmiştir. Günümüz dijital teknolojilerinin ve bilgisayar destekli modelleme programlarının pratik, güçlü ve etkili tasarım araçlarına dönüşmüş olmasına ve birçok tasarım aşamasında fiziksel modellere tercih edilmesine rağmen, maket yapımı ve kullanımı, sanat-tasarım alanlarında ve başka birçok pratik disiplinde önemini korumaya devam etmektedir (Dunn, 2010: 18). Kullanım alanlarına göre maketin işlev ve etkilerini daha iyi anlayabilmek için bu disiplinlerden belli başlı olanlarına biraz daha ayrıntılı olarak bakmakta fayda vardır.

\section{Maket Kullanım Alanları}

Sahne ve set dekorları, mimari, mühendislik projeleri ve bunlar gibi önemli miktarlarda kaynak, zaman ve yatırım harcamaları gerektiren, dolayısıyla üretim aşamalarında büyük riskler taşıyan projelerin tasarım aşamaları, sürekli tekrar gerektiren tanımlamalar, keşif çalışmaları, öngörüler ve değerlendirmeler gerektiren bir yapı oluşturmaktadır (Dunn. 2010: 5). Bu bağlamda fiziksel modeller, bir düşüncenin daha da derinlemesine keşfedilmesine olanak tanıyan katmanlar oluşturabilmektedirler. Ölçekli bir fiziksel modeli yapılmadan üretime başlanan projelerin bazı öğeleri veya bu öğelerin ölçeklerinin uyumları üretim tamamlanmadan önce tam olarak anlaşılamadığından, ta- 
sarım hatalarının bitmiş eser veya üründe büyük kusurlar olarak ortaya çıkması riski oluşmaktadır (Farrelly, 2012: 117). Bu riski ortadan kaldırma amaçlı yapılan fiziksel modelleme çalışmalarının etkilerini, çeşitli disiplinlere yayarak çoğaltmak ve örneklemek mümkündür.

\section{Sahne Tasarımı Maketleri}

Sahne tasarımında da, tasarım temelli tüm disiplinler için olduğu gibi, yaratıcı fikirlerin sunumu öncelikli bir öneme sahiptir. Tiyatroda sahneleme; seyirci kitlelerince alımlanacak açık seçimler, stratejiler ve önermeler dizisi olarak ortaya çıkar (Pavis, 1999: 233). "Süreç içinde tasarım! Tiyatroda sahne görüntüsünün biçimini oyunun genel üslubu saptar. Bir üslup bir anda oluşmaz. Çalışmanın birinci günü başlar, oyunun sahneleneceği güne kadar geçekleştirilmeye çalışılır." (Deniz, 2003: 30). Illk konseptler, modelleme teknikleri sayesinde tasarımcıya, araştırma, yeniden yapılandırma ve artan detayların içerisinde gelişen rafine fikirlere ulaşma şansı verir. Bu durum proje tasarımının, uygulama aşaması için yeterli bir olgunluğa ulaşmasına kadar sürer (Dunn, 2010: 5). Sanat dallarının çeşitlenmesi ve gelişen teknik çözümler ile tiyatro artık sadece metin-oyuncu ve sahne-seyirci değil, sanatsal olan pek çok şeyin bir araya getirildiği kolektif bir üretim olarak değerlendirilmeye başlanmış, bu sanatsal bileşenlerin bir uyum içinde buluşmasını gerekli kılmıştır. Çünkü sahneleme olgusu, bütün sanatların birleşiminden doğmakta ve bu farklı sanatsal ifade araçları arasında hiyerarşik bir ilişki de bulunmaktadır. Sahneye koyma bu ilişkilerin düzenlenmesinden oluşur (Çamurdan, 1996: 29). Sahne tasarımcısı, bu ilişkiler bütününün seyirciye aktarılması aşamasındaki görsel ve fiziksel yapının tamamından sorumlu olduğu bir noktada durmaktadır. Bu nedenle, yapacağı deneysel veya ölçekli maketler; oyunun prova aşamasında dekor ilişkilerinin görselleştirebilmesine yardımcı olurken, yönetmene de dekor, sahne ve seyirci etkileşimini bir üç boyutlu yapı olarak gösterebilecektir. Sahne tasarımcıları çeşitli tasarım aşamalarında ağırlıklı olarak maket kullanırlar. Çünkü maket dekorun üç boyutlu düzlemdeki boyutları hakkında, bir çizimin verebileceğinden çok daha fazla veriye sahiptir (Resim 4). Sahne tasarımcısı maket yapmayıp sadece çizim yaptı̆̆ında, yönetmen bitmiş dekor kütlelerine bakıp beklentileriyle uyuşmadığını söyleyebilir. Oysaki dekorun maketi yapıldığında uzamsal ilişki açıktır ve yanlış bilgilenme ve bilgilendirmeyi önleme anlamında gerçeğine çok daha yakın bir tahminle tasarım yapma olanağı sağlar (Di Benedetto, 2012: 91-92). Ay-

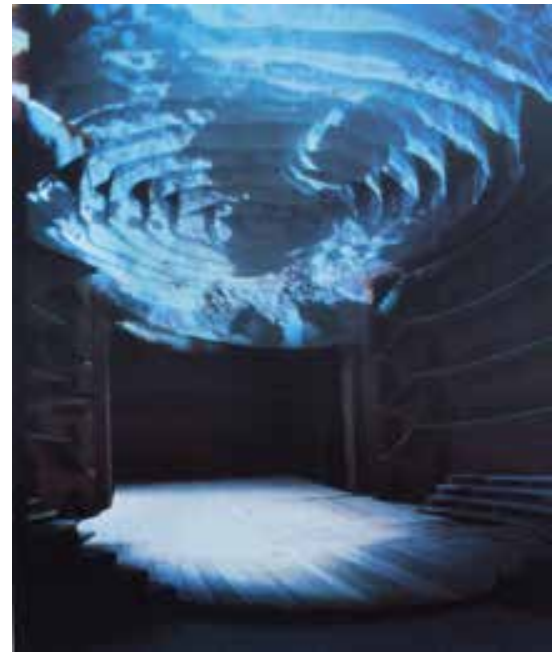

Resim 4. Joseph Svoboda'nın “Faust” operası için 1991 yılında yaptığı tasarım maketi.

rıca sahne maketlerinin yönetmene, sahne trafiğini proje henüz prova aşamasındayken çözebilmek, oyuncuların dekor içerisinde nerede durmaları gerektiğini belirleyebilmek, giriş-çıkışları ve oyun alanlarını netleştirmek, sahne üzerinde görevli tüm sanatçılara ve teknik ekibe, karmaşık sahne değişimlerinin simülasyonunu yapmak ve de diğer teknik gereksinimleri planlamak için görsel destek olarak yardımcı olabilme özelliği bulunmaktadır (Pecktal, 1975: 125-126). Dolayısıyla yönetmenler de, sahne tasarımc1larından maket isteyebilirler.

Sahne tasarımı, ancak sahne tasarımcisınin estetik yaratma enstrümanı olduğunda ve ilham veren bir atmosfer ile mekân birlikte yaratıldığında anlam kazanır. Tasarım alanı doğaçlama çalınan bir piyano gibi düşünülerek, her türlü fikrin, ne olursa olsun test edilmesi, çeşitli bileşenlerle tasarım ilişkilerinin deneylenmesi gereklidir. Herhangi bir tasarım hakkındaki farklı fikirler ancak bu türden deneyler yoluyla aynı objektif gerçekliği paylaşabilir (Svoboda, 1992/28: 19).

Dünyaca üne sahip sahne tasarımcısı Joseph Svoboda'nın bu sözleriyle ifade ettiği deneylerin sürekli tekrarlar halinde yapılabilmesinin en pratik ve etkili yolunun, maket yapımı ve kullanımı olduğunu söylemek yanlış olmayacaktır.

\section{Sinema Set Tasarımı ve Prodüksiyon Maketleri}

Tiyatroda olduğu gibi, sinema sanatının prodüksiyon aşamalarında da görsel ve mekansal estetiğin, her türlü anlatım olanağı ile sürekli olarak ilişkide olması gerekmekte- 
dir. Sinema filmlerinde maket yardımıyla fantastik ya da gerçekçi çekim mekanları ve görsel efekt oluşturma çaış̧malarının tarihi, sinema sanatının ilk örneklerine kadar gitmektedir. Örneğin, sinema tarihinin en önemli filmlerinden biri olan, Fritz Lang'ın 1927 yılında çektiği fütüristik fantezi filmi 'Metropolis'in kentsel mimari setlerinin tamamı üç boyutlu maketlerin, iki boyutlu imgelerle birlikte kullanılmasıyla oluşturulmuştur (Newton ve Sabin, 1999: 248) (Resim 5).

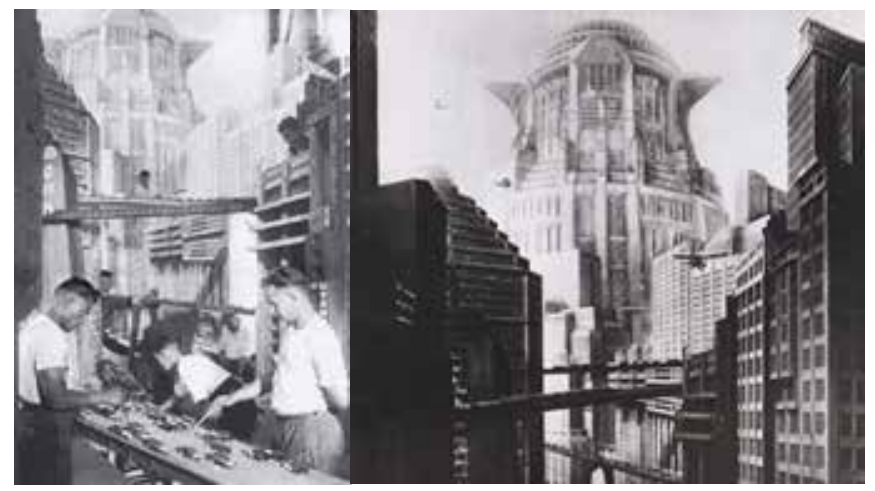

Resim 5. Fritz Lang'ın “Metropolis” filminin üç boyutlu kentsel mimari maketler ve iki boyutlu imgelerle oluşturulmuş kareleri.

Sinematografik görsellik içerisindeki, son derece gelişmiş dijital görsel efektler dünyasının tüm popülerliğine rağmen Lang'ın kullandığı bu teknik günümüzde de işlevselliğini yitirmiş değildir. Maketler, özellikle de yaratıcılığa meydan okuyan ve sanat yönetmenliğinin öncelikli bir ağırlık taşıdığı fantastik filmlerin büyük ölçekli prodüksiyonlarında, sinematografik görselliğin fiziksel setteki uygulamalarını test etmek veya tasarlamak için de bir araç olarak kullanılmaktadır (Whitlock, 2010: 320). Ayrıca, uygulanması zor bir takım sahnelerin, gerçekte inşası mümkün olamayacak mekanların, yine gerçekte oluşturulamayacak olan bazı fiziksel nesne veya oyuncu deformasyonu sahnelerinin, gerçekleri veya dijital imajlarının yerine ölçekli modellerinin yapılması ve kullanııması günümüz sinema endüstrisinde hala geçerliğini koruyan bir uygulamadır. Çünkü, dev sinema ekranında izlenen filmlerin özellikle yakın planlarında, en küçük ayrıntılar bile insan gözünün fizyolojik algılama sürecinden kaçamamaktadır. Dolayısıyla sinemanın görsel yapı ustaları da özellikle gerçeklik algısı oluşturmanın zor olduğu görsel efektler için, dijital imajların sahteliğinden kurtulmak amacıyla maket kullanmaktadırlar (Whitlock, 2010: 54). Gerçeklerinin tıpatıp benzeri olarak ölçekli bir biçimde üretilen bu özel efekt maketlerinin kaydedilen görüntüle-
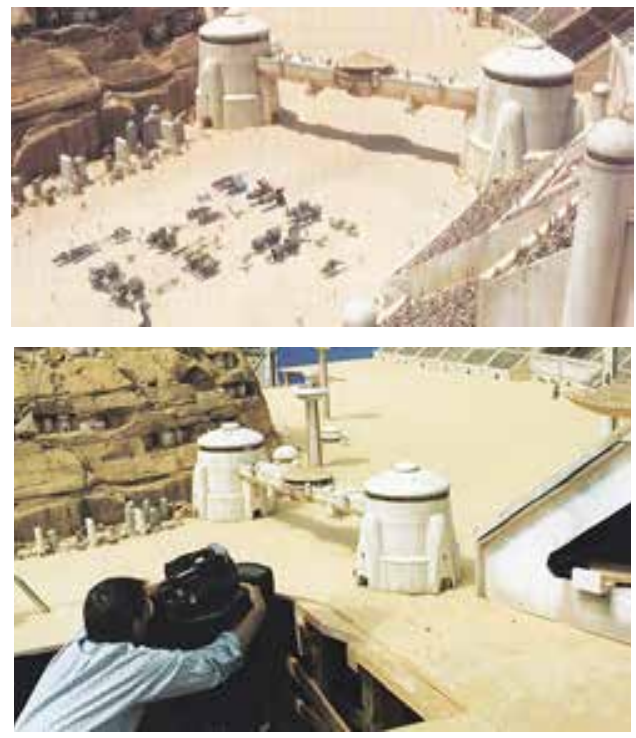

Resim 6. 1999 yapımı "Star Wars-Episode I" filminin maket setlerinden bir örnek.

ri, daha sonra bazı teknik-laboratuar ve görüntü bindirme yöntemleri kullanılarak, gerçek oyuncular veya mekanların görüntüleriyle birlikte kurgulanmakta ve üç boyutlu bir görsel illüzyon oluşturmaktadır (Resim 6).

\section{Stop Motion Animasyon Maketleri}

Sinema sanatının animasyon kulvarında bulunan ve maketlerle ilişkisi aynı zamanda varlık nedeni sayılabilecek olan 'stop motion' animasyon filmlerinin tamamı, maketlerle oluşturulan setlerde ve animasyon modelleriyle oluşturulmuş karakterlerle çekilmektedir. Bu filmlerde kullanılan gerçekçi ışık tasarımları ve maket ayrıntılama yöntemlerinin uyumlu birlikteliği, bu animatik fantezi dünyalarının son derece gerçekçi bir görsel yapıya kavuşmasına olanak sağlamaktadır (Lord ve Sibley, 2004: 79) (Resim 7).

Üretilen animasyon modellerinin hareketli olma gerekliliği bu modeller için mühendislik çalışması da gerekti-

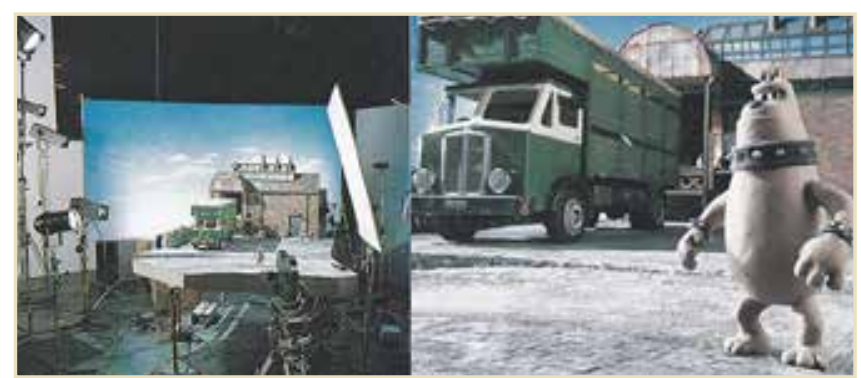

Resim 7. Nick Park'ın Çektiği "Wallace\&Gromit-A Close Shave" filminde maketlerle oluşturulan bir set. 
ğinden uygulama maketi yapılmadan önce bunların da tasarım maketlerinin yapılması ve test edilmesi söz konusu olabilmektedir. Dolayısıyla, bu disiplinin tamamen makete dayalı alt yapısı ve ortaya çıkacak olan final eserin öncesinde yapılan testlerin oluşturduğu çok katmanlı çalışma düzeni nedeniyle, maket yapımıyla ilişkide olan disiplinlerin tamamından daha fazla maket çalışmasının gerçekleştirildiği bir yapıya sahiptir (Lord ve Sibley, 2004: 94-95).

\section{Mimari Maketler}

Günümüzde bilgisayarla yapılan dijital modellemeleri en yoğunluklu kullanan disiplinlerden biri mimarlıktır. Ancak, fiziksel model yapımı mimarların antik dönemlerden beri kullanmaktan vazgeçmedikleri ve hala hem tasarım hem sunum hem de eğitim aşamalarında kullanmaya devam ettikleri bir yöntemdir. Günümüzün gelişmiş dijital modelleme tekniklerine rağmen varlığını sürdürmeye devam etmesinin belki de en önemli nedeni; giriş bölümünde de özetlenen fiziksel gerçeklik özelliklerinin sağladığı avantajlardır. Mimarların tasarım fikirlerini üç boyutlu olarak incelemek veya sunmak için kullandıkları bu maketler, mimari bir düşüncenin fiziksel yapı taşları olan genel görsel özelliklerini gösterebileceği gibi, projenin belirli öğelerini öne çıkararak onlara vurgu yapmayı sağlamak amacıyla da kullanılabilmektedirler. Maket, bir mimari tasarım fikrinin, ölçek, biçim ve malzeme özelliklerini anında ortaya koyabilir (Resim 8).
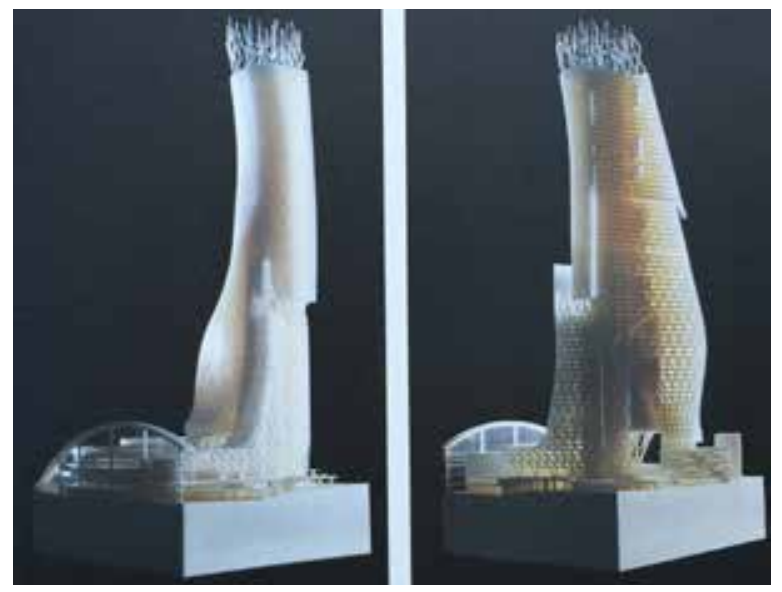

Resim 8. Paris 'Phara Tower' için yapılan tasarım maketi.

Yapısal işlev beklentisine göre birebir ölçekte, daha büyük veya daha küçük ölçeklerde de yapılabilir. Özellikle mimari projelerde, tasarlanan eserle onu çevreleyecek olan alan arasındaki ilişki de son derece önemli bir değerlendirme kriteri olabilmektedir. Bu nedenle eseri, çevresiyle ilişkisi içerisinde de değerlendirebilmek öncelikli çözümleme gerektiren bir sorun oluşturmaktadır. Bu aşamada bir binanın konumlanması planlanan yerindeki uyumuna inşa edildikten sonra bakılması yerine maket yapımı yoluna gidilmesiyle, çok hızlı bir değerlendirme süreci oluşturabilmektedir (Dunn, 2010: 6).

\section{İç Mimari Maketleri}

Ölçek anlamında genelde daha küçük odaklı sayılabilecek olan iç mimari disiplindeki maket üretiminde, mimarlıktan farklı olarak bina yapılarının kabukları yalnızca açıkıılarla tanımlanan bir kutuya indirgenmektedir. Dolayısıyla bu tür maketlerin içini dışarıdan bakan kişilere gösterebilmek için çaba sarf edilmesi gerekir. İç mekânları gösterebilmek için maketin duvarları veya tavanı açılabilir özellikte yapılır veya maket, içine girilebilir bir ölçekte yapılır (Resim 9). Ayrıca iç mimari maketlerinin bir diğer önemli özelliği; tasarlanmış mekanın içerisindeki mobilyalar, dekoratif nesneler veya gerçek yaşamda kullanılan yaşamsal iç mekan tefrişatının, küçük ölçeklerde de olsa gerçeğine en yakın haliyle üretilmesi esastır. Dolayısıyla bu tür maketler de gelişmiş bir maket yapma becerisi gerektirmektedir (Spankle, 2009: 100,101).

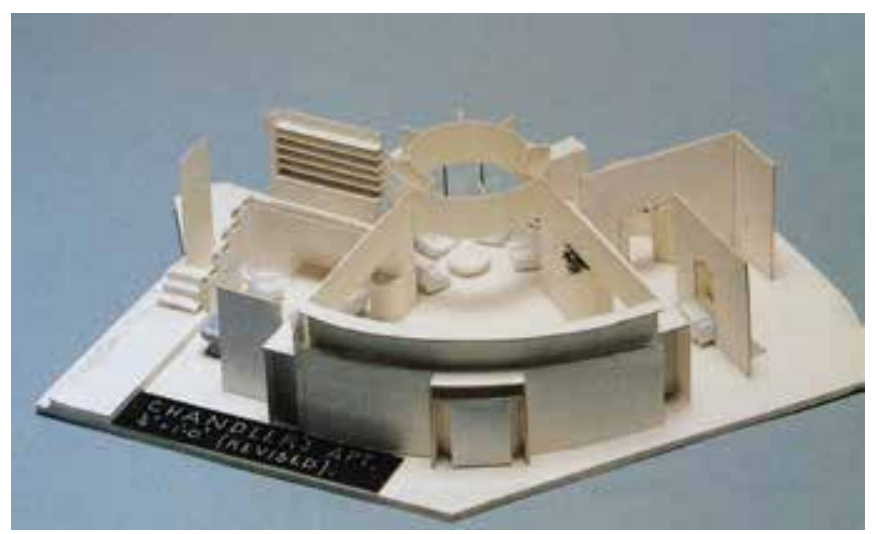

Resim 9. Bir film seti için tasarlanan apartman dairesinin iç mekan maketi.

\section{Heykel Maketleri}

Heykel sanatçıları da özellikle de büyük ölçekli tasarladıkları heykelleri üretmeden önce onun küçük ölçekli bir maketini yaparlar. Bazen de aynı mimarların yaptığı gibi projenin ayrıntılarında çözümlenmesi gereken bir nokta varsa eserin bir bölümünün bire bir ölçekli bir prototip parçasını üretirler. Mimarlarla benzeşen kullanım yöntemlerinden biri de özellikle anıt heykellerin yerleştirileceği yerle 


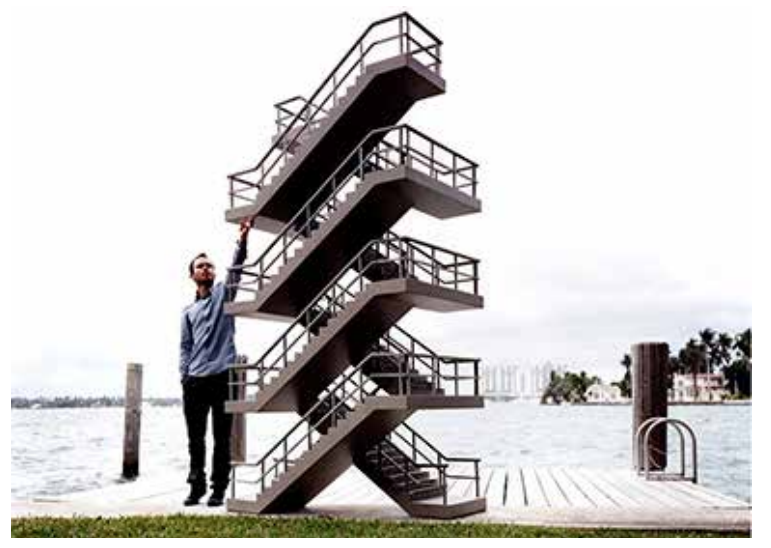

Resim 10. Daniel Arsham'ın ‘Open Staircase’ adlı eseri.

çevresi arasındaki ilişkinin çözümlenmesi aşamasında, anıt heykelin kendisini gösterebileceği bir kontrast malzemeyle üretildiği nötr özellikli ve küçük ölçekli çevresel alan maketi olarak kendisini göstermektedir (Dunn, 2010: 6). Ayrıca heykel sanatının çağdaş yorumlarında maket üretim teknikleri ile adeta bir maketmiş gibi üretilen veya maketin kavramsal mantığıyla örtüşen orijinalinden farklı malzemelerle üretilmiş nesne veya mekan kopyaları gibi kavramsal sanat ve tasarımların örneklerini, heykel veya enstalasyon projelerinin kendisi olarak da görebilmekteyiz (Resim 10).

\section{Grafik Tasarımı Maketleri}

Neredeyse zirvesini yaşayan dijital tasarım dünyasının iki boyutlu görselliğinin arasından, üretim biçimlerinin ulaşılabilirlik ve uygulanabilirliğinin arttığı, disiplinler arası uçurumların ortadan kalktığı üç boyutlu dünyaya uzanmaya çalışan ve yine üç boyutlu fiziksel medya teknikleri ile

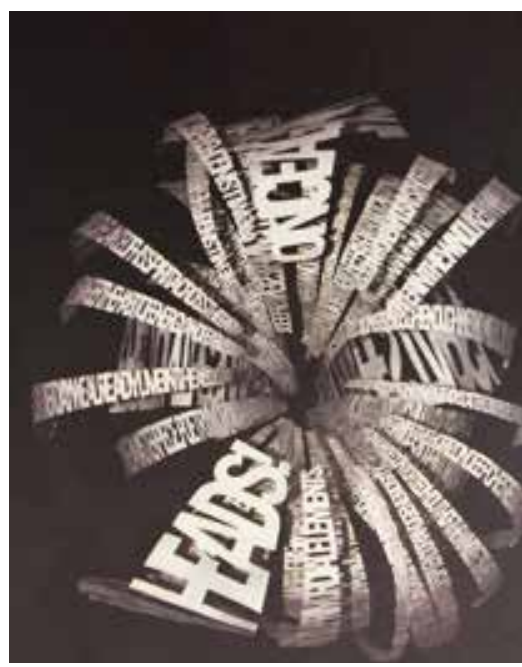

Resim 11. Ebon Heath'ın bir eseri. çalışma yapan grafik tasarımcılarının sayısı her geçen gün artmaktadır. İki boyutlu tasarımlarını üç boyutlu kolajlar haline getirerek sunan grafik tasarımcıları için, özellikle tipografinin geleneksel gridleri ve kurallarının dışına çıkarılarak dış mekanlara taşınması yöntemi, popüler bir ifade aracına dönüşmüştür (Taşçığlu, 2013: 129,130) (Resim 11). Dolayısıyla üç boyutlu tasarım olanaklarının sınırlarını keşfetmeye çalışan grafik tasarımcıları için de fiziksel model yapımı önemli bir seçeneğe dönüşmüştür.

Yukarıda sıralanan temel bazı maket kullanım disiplinlerinin yanı sıra, onlar kadar sıklıkla olmasa da zaman zaman maket kullanarak tasarım ve sunum yapma yoluna giden; endüstriyel tasarım, mühendislik, tıp ve eğitim gibi başka tasarım alanları da bulunmaktadır. Bu alanların maket bağlamında üretim nesneleri ve yöntemleri ile ilgili bilgiler, sonraki bölümde 'prototip maketleri' adlı alt konu başlığında irdelenecektir.

\section{Maket Türleri}

Vitrivius'un çok atıfta bulunulan 'kullanışlılık, sağlamlık ve güzellik' deyişi genel anlamda ve öncelikli olarak tasarım sonra da kısmen sanat disiplinlerinin temelini oluşturmaktadır diyebiliriz. Kullanışlılık nesnenin işlevselliğini ifade eder: İşe yarıyor mu? Amaca Uygun mu? Sağlamlık eserin yapısal bütünlüğünü tanımlar: Ayakta durabilecek mi? Hangi Malzemeden Üretildi? Iş̧levini yerine getirebilecek kadar sağlam mı? Kendisini veya varsa tutmak, desteklemek üzere tasarlandığı şeyleri taşıyabilecek mi? Güzellik ise eserin estetik bir değeri olup olmadığını sorgular: Güzel mi? Etkileyici mi? Görsel olarak çekici mi? Sanatçı veya tasarımcıların bu deyişin içerdiği böylesine çok yönlü beklentileri karşılama arayışı, her türlü eserin tasarım süreci için geçerli bir yapı oluşturmaktadır (Brooker ve Stone, 2011: 10). Bu noktadan bakıldığında; bu kadar fazla soruya tek bir yöntem ve teknikle yanıt verilmesi de pek mümkün görünmemektedir. Bu nedenle maket yapımı açısından baktığımızda bu sorulara yanıt bulmak için de farklı teknik ve yöntemlerle, birbirlerinden farklı amaçlara hizmet eden maketler yapılması gerekliliğiyle karşılaşmış oluruz. Maketler, herhangi bir tasarım sürecinin başlangıcından, tamamlanmış projenin sunumuna kadar herhangi bir aşamada yapılabilir. Dolayısıyla tasarım sürecinin belirli aşamalarında farklı tiplerde ve fiziksel özelliklere sahip maketler kullanma eğilimi vardır. Bu tür farklılıklarını belirleyen esaslar ise malzeme ve maketin tasarım konseptiyle kurduğu ilişkiye göre değişmektedir (Farrelly, 2012: 118). 
Genel bir bakışla maket türleri, taslak, sunum ve prototip maketleri olarak üç farklı kategoride ele alınabilir. Taslak maketi genellikle tasarım bileşenlerinin birbirleriyle ilişkisini test etmek amacıyla hızlı bir şekilde, ölçekli veya ölçeksiz olarak yapılabilir. Sunum maketleri ise ölçekli olup çoğunlukla tasarım süreci noktalanmış olan projeleri bütün gösterişleriyle gözler önüne sermeyi amaçlayan gelişmiş ve estetik kütlesel kompozisyonlardır (Brooker ve Stone, 2011: 56-57). Prototip maketler ise gerçek boyutlu(1/1 ölçekli) örnek maketleridirler. Proje hayata geçirilmeden önce bir ön deneme yapmak amacryla üretilirler (Spankle, 2012: 103). Maketin sanat ve tasarım disiplinlerinin tasarım ve uygulama aşamalarına etkilerini daha net bir şekilde irdeleyebilmek için, bu üç temel bölümlemeyi biraz daha ayrıntılı olarak ele almak yerinde olacaktır.

\section{Taslak Maketi}

Bu tür maketler ölçekli de ölçeksiz de olabilirler. Burada önemli olan ölçüler değil, fikirdir. Fikir odaklı maketler ışığı, dokuyu, sesi ya da esin veren biçimleri yansıtabilirler (Spankle, 2012: 101). Çeşitli malzemeler kullanılarak hazırlanacak üç boyutlu kütlesel modeller, tasarım projelerinin farklı açılardan kavranabilmesine yardımcı olur. Tasarım anlamında en yararlı model, düşünülen tasarım seçeneklerinin üzerinde kolayca karşılaştırılıp sınanabileceği ve kağıt, karton, kil, köpük levha, plastik, yumuşak özellikli ahşap (balsa), sac ya da eldeki en uygun bir diğer malzeme ile bunların birleşim ve yapışma özelliklerine uygun pratik yapıştırıcı kullanılarak çabucak yapılabilecek olan kütle maketidir (Frederick, 2009: 72). Bir konsept maketi, fiziksel bağlamların altta yatan felsefi düşüncelerle bağ kurabilmesini sağlayabilmek için özellikle basit bir malzeme dili kullanabilir. Bu tip bir modelde malzeme

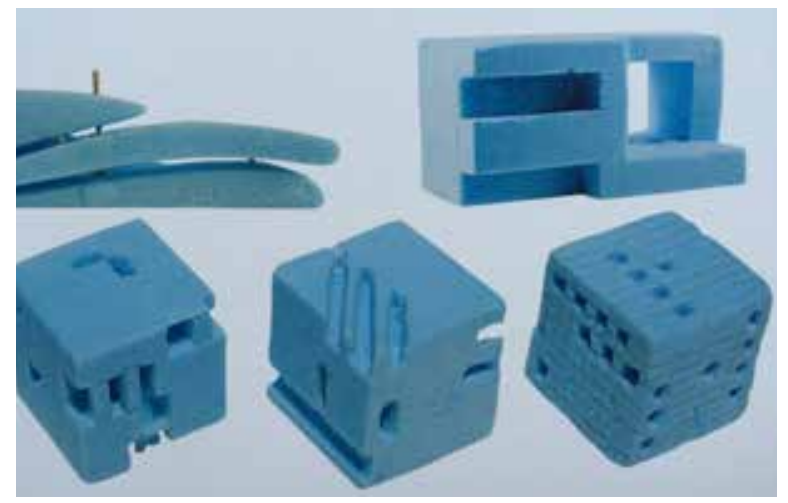

Resim 12. Taslak maketleri. Malzeme: Köpük levha. seçimi ya da renk kullanımı, düşünceleri ayrıştıran, açık ve doğru bir şekilde anlaşılmalarını sağlayan en önemli etmendir (Farrelly, 2012: 118). Bu tür çalışma maketleri tasarım sürecinin çeşitli aşamalarında üretilebildiğinden, tasarım süreci hakkında bilgi verebilir ve proje ilerledikçe radikal bir şekilde değişebilirler. Taslak maketleri üç boyutlu sorunları fark etmenin ve çözümlemenin en hızlı ve güvenilir yöntemidir ve tasarımın gelişme aşamasındaki potansiyelinin ortaya konulmasını sağlamaktadır.(Farrelly, 2012: 120) (Resim 12).

\section{Sunum Maketi}

Bu maketler projelerin nihai biçimlerini göstermektedirler. Burada kullanılan malzemelerin, nihai projede üretilmesi planlanan eserin rengini, dokusunu, fiziksel özelliklerini, ışık-gölge değerlerini ve en önemlisi de oranlarını ve ölçeğini kursuz biçimde gerçeğine en yakın haliyle yansıtabilmesi esastır (Farrelly, 2012: 121). Özenle hazırlanmış, en ince ayrıntısına kadar düşünülmüş nihai maketler tasarım

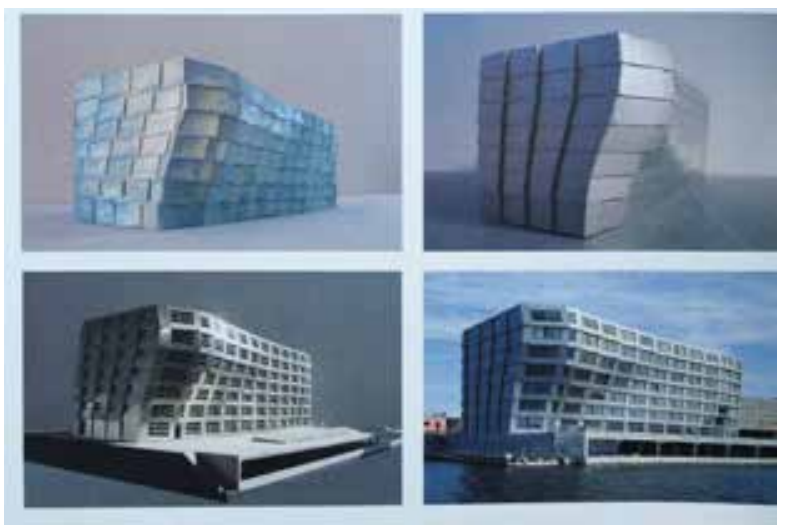

Resim 13. Almere, Hollanda'daki 'Block 16' binasının sunum maketleri ve final yapı.

aracı olarak kullanılamaz; zira bu maketler, üzerinde tartışılan fikirlerin değerlendirilmesine yardımcı olmaktan ziyade, tasarımla ilgili daha önceden alınmış olan kararları kanıtlamayı amaçlamaktadır (Frederick, 2009: 72) (Resim 13). Dijital modelleme yöntemiyle üretilmiş sunum dosyalarının, günümüzün internet paylaşım olanakları ile çok hızlı paylaşılabilmesi dijital model kullanımı önemli bir avantaj gibi görünse de paylaşılan sunum görselinin gerçeklik duygusunun sağlayacağı etkileyicilik açısından bakıldığında; fiziksel modeller sunumun yaratacağı etki bağlamında daha avantajlı bir konumda durmaktadır. Sunum maketleri genellikle, sahne tasarımı projelerinin tasarımı aşaması bitmiş yapısının açıklanmasında, tasarım süreci 
bitmiş olan mimari ve mühendislik projelerinin, anıtların ve de heykellerin kamuya veya müşterilerine tanıtılmasında kullanılmaktadırlar.

\section{Prototip Maketi}

Genellikle endüstri, mimari ve tıp alanlarında işlevsellik gösteren maketlerdir. Bitmiş tasarım nesneleri değil, belirli bir tasarım sorununun çözümü için üretilmiş deneklerdir (Spankle, 2012: 102-103). Örneğin ilk yardım ve tıp alanında kullanılan anatomik eğitim prototipleri veya ortodontistlerin diş protezleri için yaptıkları test maketleri, fizyoterapist ve ortopedistlerin ürettikleri protez uzuvlar veya ortopedik destekleri denemek için ürettikleri prototip maketleri, otomobil tasarımcılarının ve uçak mühendislerinin kütlesel çözümler için veya rüzgar testleri için ürettikleri 1/1 ölçekli otomobil ve uçak prototipleri, hatta sosyal yaşamda kamuoyu oluşturmak için yapılan gerçek ölçekli mimari cephe veya bina kesiti maketleri (Resim 14) bu kategoriye sokabileceğimiz yapıdadır. Ayrıca endüstriyel tasarımcıların ve makine mühendislerinin, tasarladıkları ürün veya mekanik parçaların bitmiş halini test etmek için ürettikleri prototip modellerini de bu kategoride ele almak mümkündür.

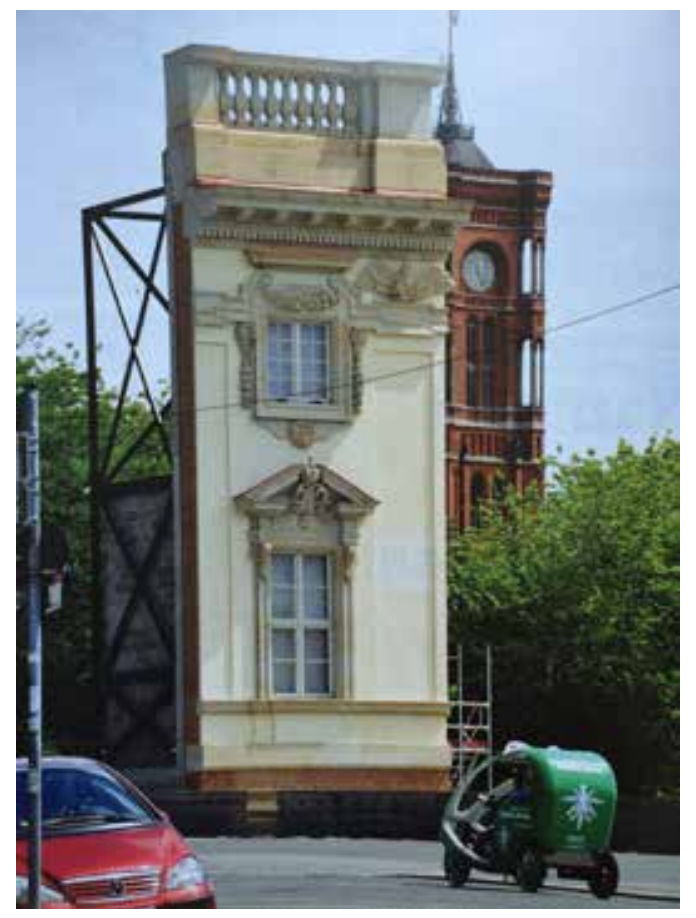

Resim 14. Berlin'de yeniden yapımı planlanan eski kral sarayının, kamuoyu bilgilendirme amaçlı yapılan $1 / 1$ ölçekli cephe kesit prototipi.

\section{Maket Yapım Malzemeleri}

Maketler herhangi bir malzemeden yapılabilirler. Örneğin çalışma maketleri ince kartonlardan, maket bıçağı ve metal cetvel gibi basit aletler yardımıyla, sunum modelleri de ahşap, metal, pleksiglas gibi malzemelerden yapılabilir. Sanat-tasarım alanında üretim yapan tüm kişilerin en aşina olduğu malzeme olan kâğıt ve karton, üç boyuta taşınmaya elverişli yapısıyla doğal olarak en yaygın maket malzemesidir. Mukavva gibi varyasyonlarıyla birlikte kağıt, üç boyutlu ürüne ya da heykele dönüşebilen, farklı renk ve dokularla zenginleşen, büyük ya da küçük ölçülerde kendini gösterebilen bir materyaldir. Kâğıdı boyutlandırma yoluyla maket denemeleri, uzun bir geçmişi olan bu tanıdık malzemeyi farklı ve yeni bir boyuta taşıyarak çok hızlı ve kolay bir şekilde çarpıcı sonuçlara ulaşılabilmesine olanak vermektedir (Taşçığlu, 2013: 131). Maket, bir önerinin sunumudur ve projenin gerçekteki uygulamasında kullanılacak malzemelerden üretilmesi gerekli değildir. Pek çok iyi maket, bulunmuş ya da geri dönüştürülmüş nesneler kullanılarak, şaşırtıcı malzemelerden üretilmiştir (Spankle, 2012: 100). Bu nedenle maket yapımında kullanılabilecek malzemeler konusunda bir sınırlama yapmak son derece yanlış olacaktır. Her maketin, yansıması ve aktarım nesnesi olduğu projenin bileşenlerine ve doğasına göre belirlenebilecek en uygun ve kendine özgü malzemelerle üretilmesi doğru olacaktır. Malzemenin sınırları, yalnızca maketi yapan kişinin malzemeye ulaşabilirliğinin, becerisinin ve hayal gücünün sınırlarıyla çevrilidir.

\section{Sonuç}

Sanat-tasarım disiplinlerinde üretim yapan kişilerin kendilerine ya da başkalarına ait fikirleri işleyerek, onu insanların eleştirebileceği bir şeye dönüştürebilmesi önemli bir gerekliliktir. Fikirlerin muhataplarına aktarılabilmesi için onlara istenilen biçimde form kazandırabilmek, en az fikirleri üretme becerisi kadar önemli bir beceriler bütünü gerektirmektedir (Owen, 1998: 13).

İşte bu beceriler bütününü içerisinde, fiziksel modellerin bir tasarım, uygulama ve sunum aracı olarak yadsınamaz derecede önemli bir rolü bulunmaktadır. Bu rolü güçlendiren öncelikli etmenler bu çalışmanın en başında vurgulanan; maketlerin, sorgulanabilen ve kolay anlaşılabilen dokuları ve de fiziksel varlıkları oluşudur. Günümüzün dijital teknoloji ve tasarım dünyasının, 3D modelleme programlarının sürat, çeşitlilik, pratik kullanım ve paylaşım yöntemleri konularındaki tartışılmaz avantajlarına 
rağmen fiziksel modeller, birçok farklı açıdan izlenebilen bir gerçekliği ve biçimi ortaya çıkarmaktadırlar. Bu nedenle birer tasarım, uygulama ve sunum aracı olarak yadsınamaz derecede önemli role sahiptirler (Farrelly, 2012: 118).

Bu çok yönlü tasarım aracının, tasarım tecrübesi anlamında da önemli katkıları bulunmaktadır. Öyle ki, bir sanatçı veya tasarımcı için, bir proje sürecinde edinip sonraki çalışmalarına aktarabileceği en değerli şeyin; önceki süreçlerin sonucunda kusursuzca üretilmiş olan nesnelerin kendisi değil, üretim süreçlerinde geliştirilmiş 'iyi tasarım yöntemleri' olduğunu düşündüğümüzde de, bir 'iyi tasarım yöntemi' olarak öne çıkmaktadır (Frederick, 2009: 31). Bu açıdan bakıldığında fiziksel olarak bir maket yapma süreci; tasarıma sağladığı katkıların yanı sıra, sanatçı ve tasarımcıya kazandırdığı gerçeklik düzlemindeki tartışma deneyimi ile birlikte, tasarımcısının mesleki yetenek ve becerilerini de geliştirecektir. Bir sanatçı ya da tasarımcının kavramsallaştırma ve görselleştirme yetisinin sınırların belirleyen temel bilgiler ve beceriler, onu tasarımcı yapan özelliklerdir. Bu bilgi ve becerileri geliştiren yapısıyla maket yapımı ve kullanımını önemli bir tasarım ve üretim yöntemi oluşturmaktadır.

Sanatçı ve tasarımcılar için, yarattıkları kavramları ve ürettikleri fikirleri uygulamak için kullanacakları medyanın ve malzemenin seçimi büyük önem taşımaktadır. Günümüzün dijital ve iki boyutlu görselliği içerisinde dokunulabilir gerçekliğin arayışı da artış göstermektedir. Çağdaş tasarımcılar, projelerini binlerce görsel mesajın arasından sıyırarak rafine bir biçimde aktarabilmek için yeni boyutlara ve açılımlara başvurmaktadırlar. Üretim biçimlerinin süratle geliştiği günümüzde yeni denemelere açılan tasarımcılar, kendilerine özgü tarz, şekil ve tekniklerini üçüncü boyuta taşımaya başlamışlardır (Taşçıŏlu, 2013: 129). Bu yapı içerisinde maket olgusu, disiplinler arası bir çağdaş tasarım ve üretim platformu oluşturmaktadır. Ayrıca bu çalışmada derlenen bilgilerin ışığı altında, maket yapımı ve kullanımının, yukarıda sıralanan tüm sanat ve tasarım disiplinleri için olduğu gibi, potansiyel başka bir çok disiplin için de verimli bir tasarlama, üretme ve de sunma biçimi olarak düşünülebileceği sonucunu çıkarmak mümkündür.

\section{Kaynakça}

Arnheim, Rudolf (2009). Görsel Düşünme, çev: Rahmi Öğdül, İstanbul: Metis.

Arredmento Mimarlık. “Dosya: Mimarlığın Maket Hali”, Sayı: 2013/02, s.72.

Brooker, Gerame - Stone, Sally (2011). Iç Mekan Tasarımı Nedir?, İstanbul: Yem Yayınları.

Deniz, Metin (2003). Tiyatroda Mekan ve İnsan, İstanbul: Maya Kitap.

Di Benedetto, Stephen (2012). Tiyatro Tasarımı, çev: Tülin Sağlam, Ankara: De Ki Basım Yayım.

Dunn, Nick (2010). Architechtural Modelmaking, London: Laurance King Publishing.

Çamurdan, Esen (1996). Çağdaş Tiyatro ve Dramaturgi, İstanbul: Mitos-Boyut Yayınları.

Farrelly, Lorraine (2012). Mimarlıkta Sunum Teknikleri, çev: Feyza Akder, İstanbul: Literatür.

Frederick, Matthew (2009). Mimarlık Okulunda Öğrendiğim 101 Şey, çev: Volkan Atmaca, İstanbul: Yem Yayınları.

Küçükerman, Önder (1996). Endüstri Tasarımı, İstanbul: Yem Yayınları.

Lord, Peter \& Sibley, Brian (2004). Cracking Animation, London: Thames \& Hudson.

Newton, Michael \& Sabin, Roger (1999). The Movie Book, London: Phaidon.

Pavis, Patrice (1999). Sahneleme, çev: Sibel Kamber, Ankara: Dost Kitabevi Yayınları.

Owen, Charles L. (1998). “Tasarım Eğitimi”, Nesnel (1):13-14

Pecktal, Lynn (1975). Designing and Painting for the Theatre, Florida: Harcourt Brace Jovanovich Publishing.

Spankle, Ro (2012). iç Mekan Çizimi ve Sunumu, İstanbul: Literatür Yayınları.

Svoboda, Joseph (1992). "The Secret of Theatrical Space”, TD\&T (28) $5: 14,19$.

Taşçıŏlu, Melike (2013). Bir Görsel Illetişim Platformu Olarak Mekan, İstanbul: Yem Yayınları.

Uçar, Tevfik Fikret (2004). Görsel Illetişim ve Grafik Tasarımı, İstanbul: İnkılap.

Whitlock, Cathy (2010). Designs On Film, New York: itbooks. 


\section{Görsel Kaynaklar}

Resim 1. Rinzler, J.W (2008). The Complete Making of Indiana Jones, New York: Del Rey. s. 45.

Resim 2. Dunn, Nick (2010). Architechtural Modelmaking, London: Laurance King Publishing. S. 14

Resim 3. http://www.sagrada.fam.22.htm/Erişim Tarihi: 21.06.2015)

Resim 4. Albertova, Helena (1992), "Even a disciplined Stage Designer has his Dreams”, Theatre Czech \& Slovak (4): 57.

Resim 5. Newton, Michael \& Sabin, Roger (1999). The Movie Book, London: Phaidon. s.248.

Resim 6. Knoll, John (2005). Star Wars-365 Days, New York: Abrams. 5.327

Resim 7. Lord, Peter \& Sibley, Brian (2004). Cracking Animation, London: Thames \& Hudson. s.78.

Resim 8. Dunn, Nick, (2010). Architechtural Modelmaking, London: Laurance King Publishing, s.155

Resim 9. Vaz, Mark Cotta \& Hata, Shinji (1994). From Star Wars To Indiana Jones, San Francisco: Chronicle Books, s.175.

Resim 10. http://www.vvork.com/?category_name=miami (Erişim Tarihi: 22.06.2015)

Resim 11. Papertag (2012)."Ebon Heath-Gözlerinizle Dinleyin", Zebra Design Factory, İstanbul, Sayı:1.

Resim 12. Zell, Mo (2008). The Architechtural Drawing Course, London: Thames \& Hudson, s.118.

Resim 13. Dunn, Nick (2010). Architechtural Modelmaking, London: Laurance King Publishing, s.156.

Resim 14. Arredmento Mimarlık. “Dosya: Mimarlığın Maket Hali”, Sayı: 2013/02, s.76 